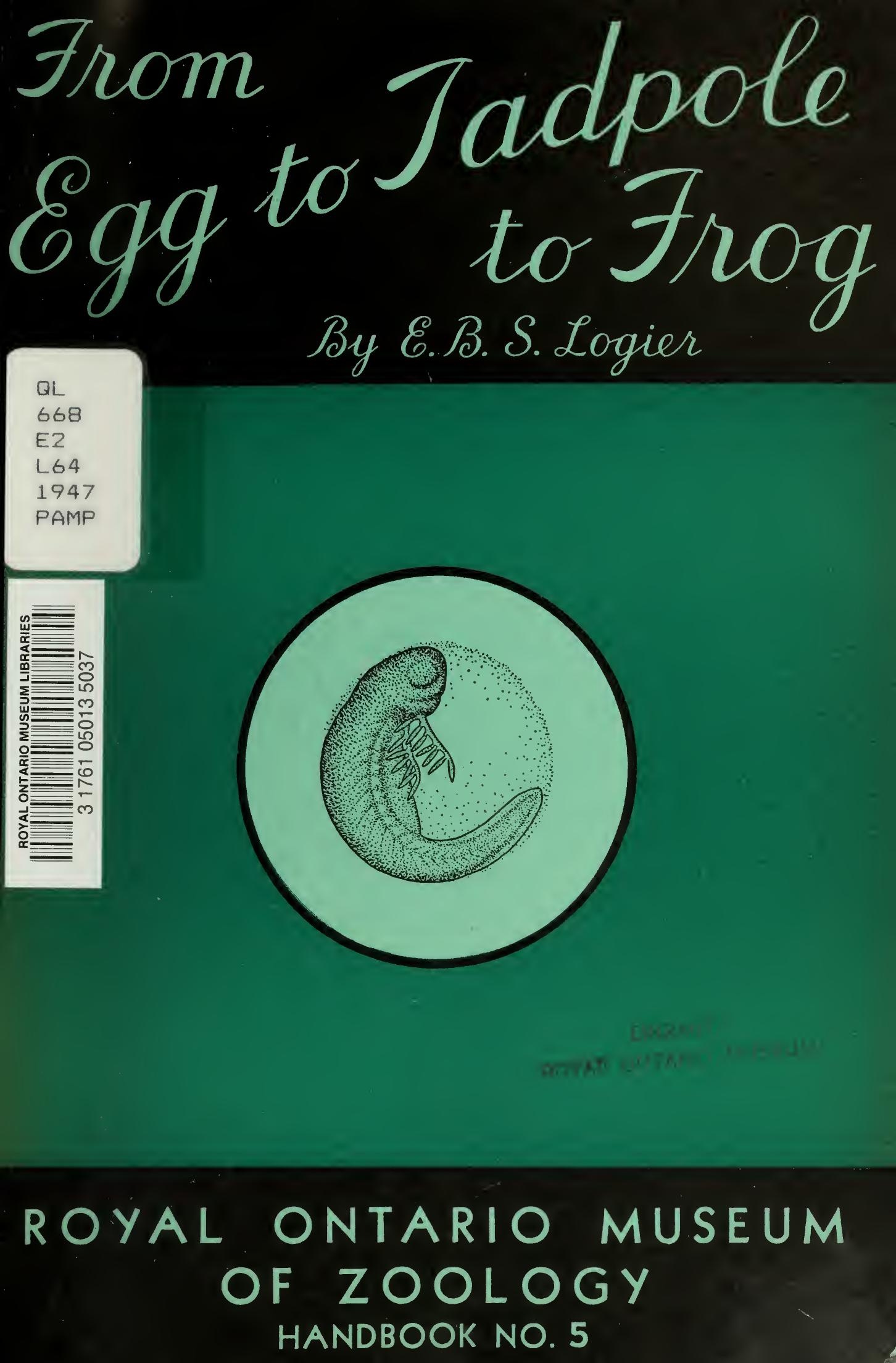



H A N D B O O K $\mathrm{NO} .5$

\title{
From Egg to Tadpole to Frog
}

\author{
BY \\ E. B. S. LOGIER
}

ILLUSTRATIONS BY THE AUTHOR

PUBLISHED BY

Royal Ontario Museum of Zoology 1947 
Printed by UNIVERSITY OF TORONTO PRESS 


\section{FROM EGG TO TADPOLE TO FROG}

A SCIENTIST ONCE SAID, "THE GREATEST AND MOST FARreaching theme that has ever occupied the minds of men is the problem of development." How a living creature with its complicated body composed of many different parts and organs perfected for their various uses, and its amazing endowment of senses and behaviour, can be evolved from such a seemingly simple thing as an egg, has been well described as "the climax of all wonders."

In most kinds of animals with which we are familiar it is not possible to watch the living egg change into an embryo, and the embryo develop into a perfect animal. Eggs are so often enclosed in opaque shells, or if not, are concealed within the body of the parent until hatched.

In the case of many of the lower vertebrates (animals with a backbone) such as fishes and amphibians, and in various invertebrates (animals without a backbone), the covering of the egg is transparent and serves as a window through which we may watch this wonderful process.

The eggs of frogs and toads serve well because they are fairly large in size, their envelopes are transparent, and they are easily obtained. Further, they are easily cared for and are not injured by temperature changes of moderate range while hatching.

All of our Canadian species of frogs and toads lay their eggs in water, and though their habits may differ, the pattern of their development and life history is essentially the same. The time of egg laying varies with the 
temperature of the season, the latitude of the locality and the species of frog. In an "early" spring, for example, frogs will begin laying sooner than in a "late" one. Also, in a southern locality, such as the Lake Erie region, the same species might be expected to commence three or four weeks earlier than in a northern one, Lake Nipigon for example, due to geographic differences in temperature of air and water. There are also differences in time of laying which are due to natural variations between one and another species of frog. For instance, wood frogs in the Lake Ontario region usually start spawning early in April, while bullfrogs in the same locality might not start until the middle of June, or later. From this it will be seen that there is a considerable period during spring and summer when frogs' eggs of one or another kind may be available for those who wish to study them.

For the purpose of observing hatching and development, the eggs of any species will do, for they all go through the same processes. However, the length of time from egg to metamorphosis (transformation to frog) is longer for some than for others. The wood frog, leopard frog, and toad are very common and widely distributed in Ontario. They spawn in the small, often temporary, ponds scattered about the country and finish their metamorphosis in one summer. Thus they are convenient species from which to select your study material. The eggs of pond frogs are laid in jelly spheres which adhere together in clumps (fig. 1), while those of toads are laid in long spiral tubes of jelly in the form of strings (fig. 2).

If you visit a frog pond in the spring when the frogs are spawning (after dark is the best time; use a flashlight) you will notice that the spawning frogs are in pairs. Each pair is a male and a female. During egg-laying, at the same moment when eggs (female reproductive 
cells) are passed out into the water from the oviducts of the female, a milky fluid called milt, containing sperm (male reproductive cells) is emitted by the male. Sperms swim freely in the water about the newly laid eggs. A sperm enters each egg and unites with it, a process called fertilization. This is the first essential step before an egg can develop and hatch into a young animal, whether it

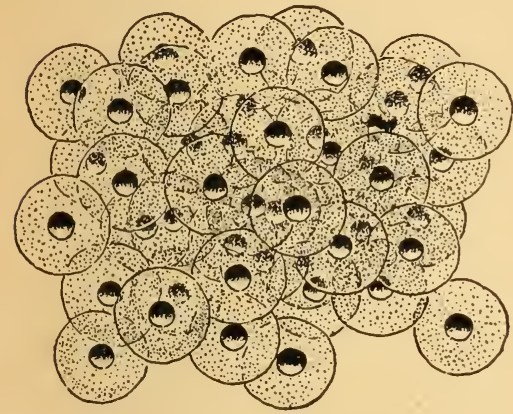

Fig. 1

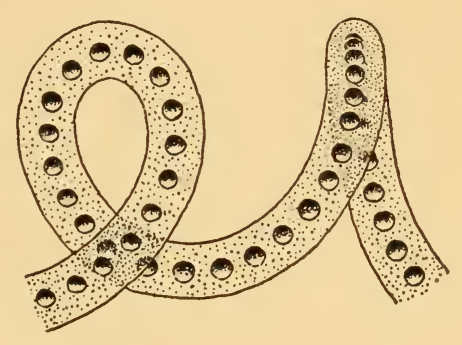

Fig. 2

be a fish, a frog, a reptile, a bird or a mammal. They all start with a fertilized egg.

If we select the wood frog as our species, watch the pond nearest your home when April comes, and when the wood frogs begin to spawn you will hear them croakingthey make quite a noise, rather like ducks quacking. The eggs will be found in shallow water, six inches to one or two feet deep, and usually near the edge of the pond if it is a large one. They will be in roundish clumps of jelly (fig. 1), each containing hundreds of eggs. Usually they are attached to twigs or grass stems, but occasionally they are unattached and lying on the bottom. Transfer a clump of eggs to a wide-mouthed jar (you can float them in) with enough water to nearly fill the jar. Take them 
home, or to your schoolroom, and place them in a hatching aquarium (a large pie dish or wash basin will do).

Remove an egg from the clump, place it in a small dish of water and examine it with a good hand lens (about 6 to 10 power) and note: The egg itself is a small, opaque ball about one-twelfth of an inch in diameter. The upper half is black or dark brown and the lower half, which contains most of the yolk, is white or creamy (fig. 3). Sur-

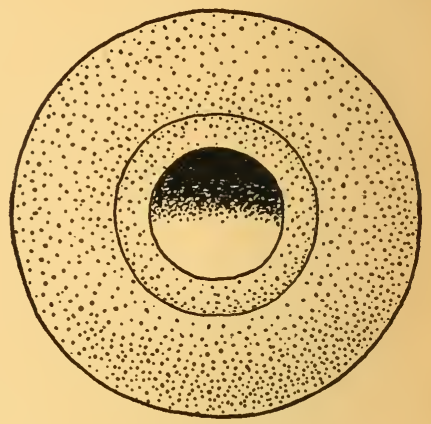

Fig. 3 rounding the egg are two envelopes of transparent jelly (fig. 3). The outer one is about a quarter-inch, or slightly more, in diameter. The inner one is much smaller, lies close to the egg, and may be difficult to see unless your lens is strong. The inner envelope is present in the eggs of all but three kinds of our frogs, namely: the swamp tree-frog, peeper, and bullfrog.

Since development progresses quickly indoors at room temperature, it would be advisable to remove and examine an egg about three times a day. If you look carefully, using a good lens, you will be able to observe the following steps and stages as the eggs develop. First, a groove appears vertically around the egg, cutting through and dividing it into two cells which adhere together (fig. 4). Crosswise to this another vertical groove appears and cuts through, thus dividing the embryo (for it is no longer just an egg) into four cells (fig. 5). The third groove to appear cuts through horizontally, above the middle, dividing it into eight cells, the upper four of which are smaller (fig. 6). From here on cell division is rapid and as the cells increase in number they decrease in size. 
The cells of the black, upper portion of the embryo multiply more quickly than those of the white, lower part, so they soon grow downward over the yolk and cover

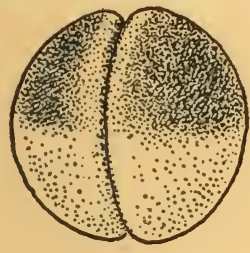

Fig. 4

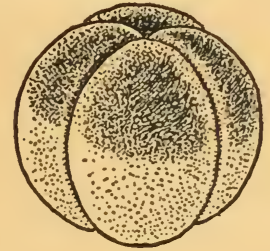

Fig. 5

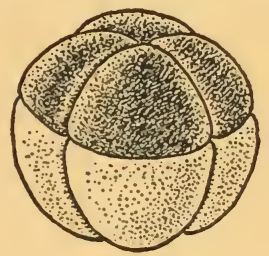

Fig. 6

it, leaving exposed only a little white spot called the yolk plug (fig. 7). The individual cells will now be too small to see without a compound microscope, but the beginnings of various structures may be seen with the hand lens. The embryo tadpole begins to lengthen from head to tail ends and a groove appears lengthwise along the back. (fig. 8). This is the neural groove, and is the early beginning of the spinal cord and brain. The white yolk

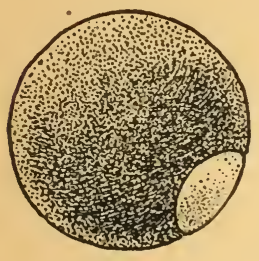

Fig. 7

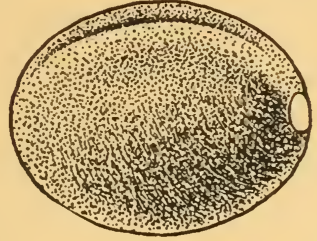

Fig. 8

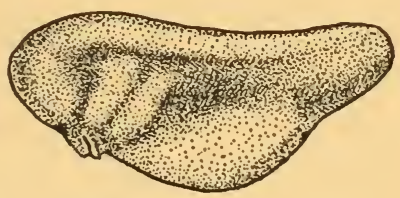

Fig. 9

plug, which is at the tail end, is soon covered by the rapidly growing black cells, and a small conical projection appears in its place (fig. 9). This is the beginning of the tadpole's tail. The neural groove closes to form a canal, the lining of which will give rise to the central nervous system. 
The head region becomes marked off from the body, and if you look very carefully you may be able to see on each side of the head a series of two or three obliquely, vertical ridges (fig. 9). All three may not be clearly visible. These will develop into the gill-arches from which the gills will grow (fig. 11). The depressions between them will become the gill-clefts and will communicate with the inside of the mouth. Little fleshy tufts begin to grow
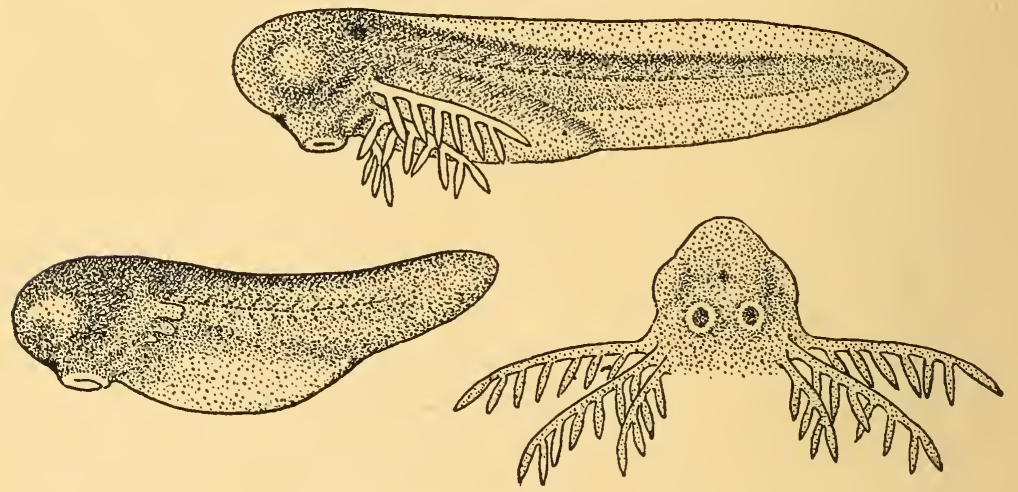

Fig. $10 \quad$ Fig. 11

Fig. 12

back from the first two gill-arches (fig. 10) and will develop in to external gills.(fig. 11) by means of which the young tadpole will breathe for a few days. The crescentshaped groove (fig. 10), which has already appeared beneath the front part of the head, will divide into two, forming the pair of adhesive organs (figs. 11,12) by wihich the baby tadpole will cling to grasses and twigs. The small depression in front of this (fig. 12) will develop into the mouth. The future eyes may now be indicated by a rounded swelling on each side of the head (fig. 11), and the ears by a faint depression above the gill region of each side (fig. 11). Beneath the base of the tail bud, 
a small pit may be visible which marks the position of the vent (fig. 10).

The tail lengthens and begins to develop a fin (fig. 11), the gills become larger, the adhesive organs form into two disks (fig. 12), the swellings of the eyes become more apparent, and the baby tadpole hatches in this condition. A few more days will probably have to pass before it can see or feed, for the eyes are still only swellings and the mouth and vent have not yet established their connection with the intestinal tract. Wriggling free from the jelly envelope, which is now disintegrating, the tiny tadpole clings by its "suckers" to the outside of the jelly mass, or to nearby twigs or weeds, and is nourished by the remains of the yolk stored in its body.

A third, but smaller, pair of external gills grows out from the corresponding pair of gill-arches (fig. 11, 12). The vent first, and then the mouth, establish connection with the intestinal tract; the eyes become functional, and the young tadpole, now able to see and feed, swims about more freely. The mouth develops horny jaws and fleshy lips with rows of tiny rasping teeth. The external gills begin to shrivel and are replaced by internal gills (like those of fish) which grow from the inner side of the same arches. A flap of skin, the operculum, grows backward on each side of the head, covering the gills, and its margin unites with the skin of the body wall behind the gill region, thus enclosing the gills and their arches in the gill chamber. On the left side a small tube-like spout called the spiracle (fig. 13) remains open to the outside. Water is taken into the mouth, passed through the gillclefts and over the gills, thus aerating them, and is expelled through the spiracle.

The tadpole grows rapidly and the body becomes broader and more oval in outline (figs. 13, 14) as the 
various internal organs develop. The intestine lengthens greatly and becomes coiled in spiral fashion and may be seen through the transparent skin of the belly. Lungs develop and become functional, both as hydrostatic organs (organs of floatation) and as aids to the gills in respiration. Now the tadpole occasionally comes to the surface and takes in a gulp of air. It has become truly amphibious. The tiny buds of the future hind limbs appear on either

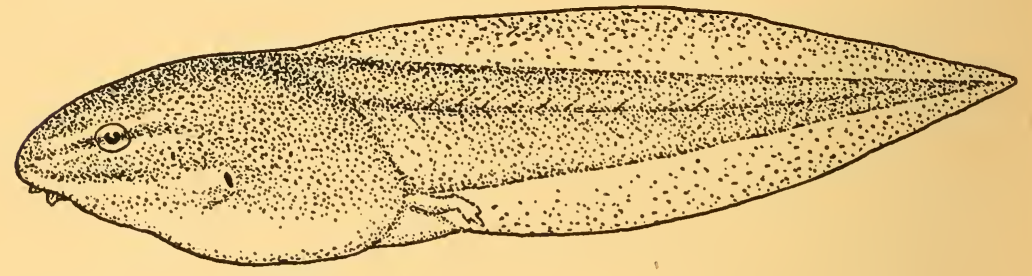

Fig. 13

side at the root of the tail (fig. 13), and grow rapidly. Meanwhile, unseen, within the operculum, the front limbs also are growing and developing.

As the time of metamorphosis (change from tadpole to frog) approaches, the gills begin to shrivel away and the lungs take over the work of breathing. The limbs attain full development (fig. 15) and the front pair, which have been concealed, break through the operculum and appear suddenly, often on the left side first. Their escape is aided by a secretion from the degenerating gills which digests away a small patch of skin on each side of the operculum, making an opening. The mouth widens and loses its horny jaws and large fleshy lips with their rows of small rasping teeth; and true teeth develop on certain of the bones of the mouth. The tail diminishes in size (figs. 15, 16) and finally disappears. But its material is not wasted; it is digested and used to nourish the trans- 
forming frog during the days when the structure of its mouth is changing and it is unable to feed. As a tadpole it fed upon both plant and animal matter which were bitten or rasped off in small pieces and swallowed, but as a frog it will no longer use vegetable food.

The little froglet leaves the water before the tail is absorbed. In appearance it rather resembles a tiny lizard (fig. 15). By the time the tail has disappeared the changes in the mouth will be completed, and the tiny frog will be able to feed by snapping up insects with its sticky tongue. These it swallows whole. Metamorphosis is then complete and from that time on the frog will spend much of its time on land in dampish places. Several years will be required for it to become adult, able to mate and reproduce its kind. But after it is thus mature, it may still grow a little more.

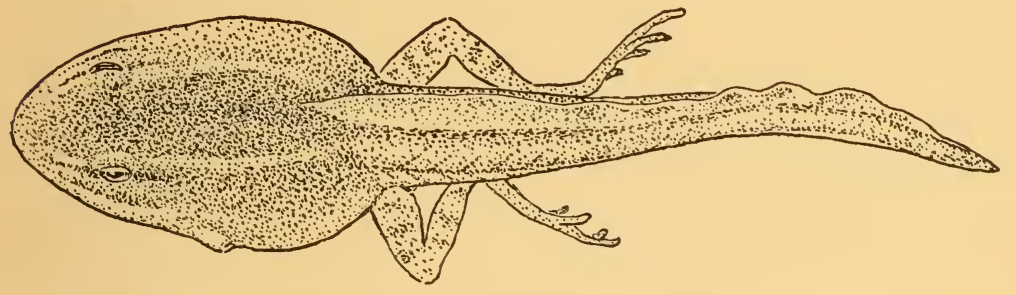

Fig. 14

With two exceptions, all our frogs complete their metamorphosis from egg through tadpole to frog in one summer. The exceptions are the green frog, which requires one full year, and the bullfrog, which requires two years.

A frog takes no motherly interest in its eggs beyond that of laying them in water, and no interest at all in the young. The eggs themselves are fairly well protected while developing, enclosed as they are in their tough jelly envelopes. The real dangers for the young begin 
when they leave the jelly envelopes. They are completely defenseless, and are eaten in large numbers by newts (and other salamanders and their larvae), by hordes of predaceous insects such as diving beetles and their killer larvae, the "water-tigers" that inhabit the pond. The greatest destruction occurs while the tadpoles are very small, but throughout their aquatic life they fall easy prey to hosts of hungry enemies. Often, too, a temporary pond dries up before the tadpoles have completed their growth so that the whole population in a pond is destroyed. It follows, then, that of the countless thousands that hatch every spring, relatively few live to change into frogs.

When the little froglets leave the water a new gamut of dangers begins. Big frogs often snatch up little ones, and birds such as bitterns, herons and kingfishers which

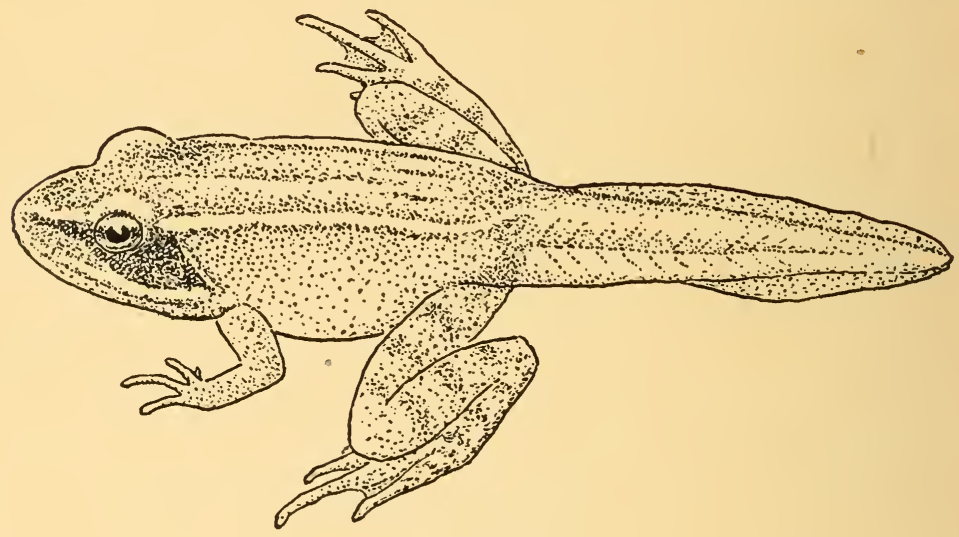

Fig. 15

forage along the shores of ponds, eat multitudes of them. Garter snakes and water snakes also take their toll. Again, this destruction is greatest while the frogs are small, but it continues to some extent throughout life, so that even out of the relatively small number that attain to transformation, few live to grow up and reproduce their kind. 
You can see why it is necessary for frogs to lay so many eggs. The wood frog lays from 2000 to 3000 , and the toad from 4000 to 7000. Animals like birds and mammals that take active care of their young do not need to produce so many. The numbers of young produced must bear some relationship to the dangers to which they are exposed and thus provide a margin of safety to insure the survival

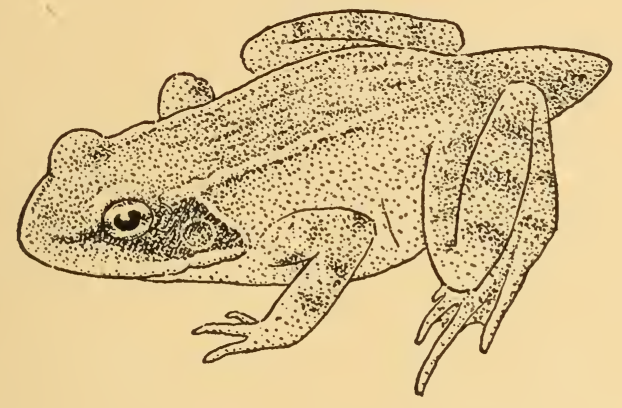

Fig. 16

of a few in each generation. On the other hand, when the reproductive power of a species of animal, such as a frog, becomes greatly increased to meet these dangers, the dangers themselves become a necessity in order to control excessive numbers of the animal. For example, if by some miracle all the young of a single pair of wood frogs were to live to grow up and reproduce young, and all their young in turn were to do the same thing, there would be over two billion frogs (and perhaps two or three times that many) in the third generation from the single pair. With such a rate of reproduction and no checks, soon there would not be living space on earth-not enough food and fresh water to meet their requirements.

All through the living world the opposing forces of production and destruction are in continual conflict 
with each other-they are both very important-and the constant readjustment between the two is known as the balance of nature. Without this balance life could not continue to exist.

Now, a word about caring for your tadpoles. Don't crowd them; give them enough space. The best container is an aquarium tank with two or more square feet of floor area. Failing this, use a large dishpan or a washtub. Lay sand about an inch deep on the bottom (not essential, but desirable), and pour in water to about six inches in depth. Add some aquatic weeds and green algae from the pond. It is best to put the eggs directly into this aquarium to hatch. You will not be able to raise all the hundreds of tadpoles that hatch from your clump of eggs, nor should you try to do so. A few dozen will be enough. However, many will probably die during the first few days, and many more during the succeeding weeks. Dead tadpoles that are not soon eaten by the living ones (as many will be) should be removed to avoid fouling of the water.

To feed your tadpoles, use such foods as raw beef scrapings, crushed raw liver, raw fish, fresh green peas boiled and crushed, crushed spinach (raw or cooked), boiled potato or carrot, whole wheat bread, puppy biscuit, and the highly desirable package food called "Pablum." Aquatic weeds and green algae are eaten by wild tadpoles and should be supplied. It is not necessary to use all of the foods listed above, but use a few and be sure to use some animal and some green plant food. The use of some Pablum is recommended since it contains minerals and vitamins that might otherwise be missed in an artificial diet. Feed restricted quantities which are thoroughly consumed. Meat foods that are not eaten within a few hours should be removed with a syphon or 
dip tube, otherwise they will putrefy and pollute the water.

When the tadpoles near the time for transformation into frogs the depth of the water should be reduced to one or two inches, and some sloping stones supplied for the young frogs to climb out on, otherwise they will drown as would any other land animal that is forced to remain in water over its depth. The aquarium should be covered with a pane of glass to keep out house dust, check evaporation, and prevent escape of young frogs until they can be removed and returned to the pond. Those that live to transform should always be returned to the pond (except the few that you might wish to keep as pets). Living animals should never be allowed to die from neglect. Never deliberately kill them unless some definitely useful purpose is served. Mature frogs may be fed with living insects and small worms. Also they will learn to take little pieces of meat from the point of a forceps or toothpick. You will find them interesting pets.

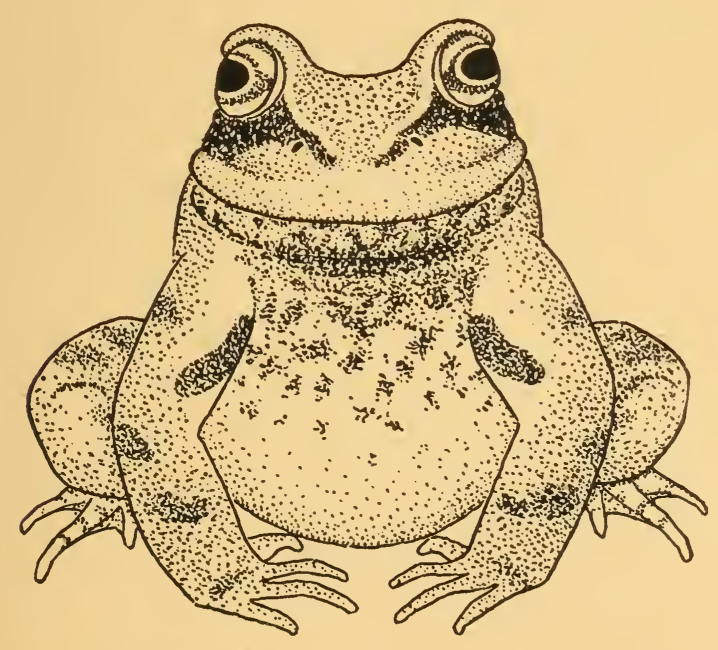





\section{HANDBOOK SERIES}

(unnumbered), Guide to the Game Fishes of Canada, (by J. R. Dymond). 20 pages. 1927. (Out of print.)

No. 1, The Mammals of Ontario, by E. C. Cross and J. R. Dymond, 55 pages. 1929. (Out of print.)

No. 2, The Hawks and Owls of Ontario, by L. L. Snyder. Pen and ink drawings by T. M. Shortt. 48 pages. 1932. Revised edition.

No. 3, The Amphibians of Ontario, by E. B. S. Logier. Pen and ink drawings by the author. 16 pages. 1937. No. 4, The Reptiles of Ontario, by E. B. S. Logier. Pen and ink drawings by the author. 81 pages. 1939.

No. 5, From Egg to Tadpole to Frog, by E. B. S. Logier. Pen and ink drawings by the author. 16 pages. 1947. 
